\title{
Effect of Dietary Protein on Vitamin E Levels in Erythrocytes and Tissues of Rats
}

\author{
Kayo MOURI, ${ }^{1}$ Yoshiko HAYAFUnE, ${ }^{2}$ and Osamu IGARASHI ${ }^{2}$ \\ ${ }^{1}$ Toyoko Gakuen Women's Junior College, \\ Todoroki, Setagaya-ku, Tokyo 158, Japan \\ ${ }^{2}$ Institute of Environmental Science for Human \\ Life, Ochanomizu University, Ohtsuka, \\ Bunkyo-ku, Tokyo 112, Japan
}

(Received September 11, 1985)

\begin{abstract}
Summary The effect of dietary protein level on the transfer of $\alpha$ tocopherol in blood to tissues including $\mathrm{RBC}$ was studied using rats. The first experiment comprised a $10 \%$ casein (low protein), $20 \%$ casein (normal) and $20 \%$ SPI (normal soybean protein) diet groups supplemented with $71.5 \mathrm{mg}$ of $\alpha-\mathrm{Toc} / \mathrm{kg}$ diet. In Exp. 2 the relationship of the tissue $\alpha$-Toc level and protein level in diets, as shown by recovery from vitamin E-deficient status after the administration of $\alpha$-Toc for 3 days, was checked by adjusting the protein level in diets to $10 \%, 20 \%$ and $40 \%$ casein. In Exp. $1 \alpha$-Toc in RBC decreased significantly in the $10 \%$ casein and $20 \%$ SPI groups compared to the $20 \%$ casein group. Moreover, $\alpha$-Toc in kidney, lung and muscle decreased significantly in the $10 \%$ casein and $20 \%$ SPI groups. $\alpha$-Toc in liver in the $20 \%$ SPI group decreased significantly compared to the $20 \%$ casein group. In Exp. 2 similar results were observed (Table 4), but $\alpha$-Toc in RBC showed only a tendency to decrease with the low protein diet. In Exp. 1 free cholesterol in RBC increased significantly in the $10 \%$ casein group compared with the other two groups. Key Words $\alpha$-tocopherol concentration in tissues, erythrocyte $\alpha$-tocopherol level, protein level in diets, transfer of $\alpha$-tocopherol, vitamin Edeficient
\end{abstract}

In a previous paper ( 1$)$, it was shown that the transfer of circulating vitamin $\mathrm{E}$ ( $\alpha$-tocopherol, $\alpha$-Toc) to erythrocytes (RBC) in rats was affected by the quantity and quality of dietary protein, even when the serum $\alpha$-Toc was kept at exactly the same level in all dietary protein groups. When the dietary casein level was kept at a level lower than $10 \%, \alpha$-Toc in RBC significantly decreased as compared with the control $(20 \%$ casein) group. This occurred independently of the level of serum

${ }^{1}$ 毛利佳世, ${ }^{2}$ 早船佳子, 五十嵐脩 
cholesterol. The effect of soy protein isolate (SPI) was examined and compared to casein in the previous study (1). $\alpha$-Toc levels in serum and RBC were lower in the SPI group than in the casein group, both at $10 \%$ and $20 \%$ dietary protein levels. The reason why dietary proteins affect tocopherol concentrations is assumed to be secondary to changes in protein concentrations affiliating to tocopherol, such as lipoproteins in serum and binding proteins in tissue cells, since it has been recognized that tocopherol is localized in lipoproteins in serum (2), while it exists in a form bound with specific binding proteins in RBC membranes (3) and in cytosol in tissue cells of liver, small intestine, lung and kidney (4-7).

Half of present investigation was attempted to further extend and confirm the above results, especially changes in tocopherol concentrations in several tissues besides the liver, by a trial with a similar dietary protein. $\alpha$-Toc in RBC responded to the quantity and quality of dietary protein, while $\alpha$-Toc in liver did not. Clinically, RBC or platelet $\alpha$-Toc was used to evaluate vitamin E status (8). It is important to know whether the RBC $\alpha$-Toc level interrelates with $\alpha$-Toc levels in tissues such as kidney, lung, heart and muscle under low-protein nutrition or not. The other half of the present investigation was attempted to determine the effect of dietary protein on $\alpha$-Toc levels in tissues including RBC after recovery from $\alpha$-Toc deficiency by refeeding $\alpha$-Toc.

\section{EXPERIMENTAL}

\section{Animals and feeding}

Male Sprague-Dawley strain rats weighing 120 to $150 \mathrm{~g}$ initially were fed the following standard diet for a week: vitamin-free casein, $20.0 \%$; sucrose, $63.8 \%$; vitamin E-free stripped corn oil, $8.0 \%$; mineral mixture, $4.0 \%$; vitamin mixture, $1.0 \%$; choline chloride, $0.2 \%$; and cellulose powder, $3.0 \%$. Compositions of the mineral mixture and vitamins except for vitamin E followed Harper (9).

Experiment 1. Animals were divided into 3 groups (each group containing 10 animals): $20 \%$ casein, $10 \%$ casein and $20 \%$ soybean protein isolate (SPI)-fed groups. In the $10 \%$ protein group the protein level in the diet was adjusted by sucrose. For SPI commercially available. Fujipro-R was used and kindly donated by Fuji Oil Manufacturing Co., Osaka, Japan. This SPI was prepared from soybean extract after heat treatment to inactivate trypsin inhibitors. Animals in each group were pair-fed with $17 \mathrm{~g} /$ day of the diet for 6 weeks. $\alpha$-Toc levels in each diet were kept at $71.5 \mathrm{mg} / \mathrm{kg}$ diet during feeding. Tocopherol contents. in SPI were as follows: $\alpha$-Toc 76, $\gamma$-Toc 164 and $\delta$-Toc $94 \mu \mathrm{g} / \mathrm{kg}$.

Experiment 2. The rats were prefed a diet containing $\alpha$-Toc $(71.5 \mathrm{mg} / \mathrm{kg}$ diet $)$ for 1 week, and then divided into 3 groups (10 animals each): the $40 \%, 20 \%$ and $10 \%$ casein groups. After a vitamin E-deficient diet had been administered for 6 weeks by pair-feeding (daily intake $17 \mathrm{~g}$ ), about half of the animals in each group were sacrificed and the remaining animals were fed a vitamin E-supplemented diet $(d l-\alpha$-Toc $71 \mathrm{mg} / \mathrm{kg}$ diet, daily intake $10 \mathrm{~g}$ ) for 3 days. The daily intake of $\alpha$-Toc for each animal was ca. $2.5 \mathrm{mg} / \mathrm{kg}$ body weight. 
Before sacrifice the animals were fasted overnight. Blood was drawn from the aorta after ethyl ether anesthesia. Part of the blood was heparinized for separation of $\mathrm{RBC}$ while the remaining blood was untreated with heparine to separate serum. Liver, kidney, lung and skeletal muscle (musculus quadriceps femoris) were used to analyze the $\alpha$-Toc level and 2-thiobarbituric acid reactive substances (TBARS).

\section{Materials}

$d l-\alpha$-Toc for diets and the authentic specimens of $d-\alpha-, d-\beta-, d-\gamma-$ and $d-\delta$ tocopherols for high performance liquid chromatography (HPLC) were kindly donated by Eisai Co., Ltd., Tokyo. 2,2,5,7,8-Pentamethyl-6-hydroxy-chroman (PMHC) as the internal standard for HPLC was synthesized in our laboratory using the method of Smith et al. $(10,11)$.

\section{Analytical methods}

Total cholesterol in serum was determined by the enzymatic method using a kit from Kyowa Fermatation Co., Ltd., Tokyo. $\alpha$-Toc in serum was determined by HPLC following the method of Abe et al.(12), and that in tissues and RBC was similarly determined by HPLC after saponification following the method of Abe $e t$ al. $(13,14)$. PMHC as an internal standard was added to the extract as $n$-hexane solution before HPLC.

Free cholesterol in RBC was determined following Rose's method as modified by Shibata et al. (15). Lipid peroxide amounts (TBARS) in RBC were determined by the method of Brownlee et al. (16) and those in liver by the method of Uchiyama and Mihara (17).

\section{RESULTS}

\section{Experiment 1}

Table 1 shows $\alpha$-Toc concentrations in RBC and serum, and total cholesterol level in serum and free cholesterol in RBC in the $10 \%$ and $20 \%$ casein groups and the $20 \%$ SPI group, respectively. $\alpha$-Toc in RBC was significantly higher only in the $20 \%$ casein group as compared with the other groups, while $\alpha$-Toc and total cholesterol in serum did not differ from each other. $\alpha$-Toc in sera of the $20 \%$ and $10 \%$ casein groups was slightly higher than that of the $20 \%$ SPI group, but the difference was statistically not significant. In the $10 \%$ casein group, free cholesterol in $\mathrm{RBC}$ significantly increased compared to that in the $20 \%$ protein group, but it did not differ between the $20 \%$ protein groups.

In Table 2 the $\alpha$-Toc concentrations in tissues, liver, kidney, lung and muscle are shown. The $\alpha$-Toc concentration in every tissue of the $20 \%$ casein group was higher than in the other two groups. In the $10 \%$ casein and $20 \%$ SPI groups there was no difference in the $\alpha$-Toc level in any of the tissues examined.

\section{Experiment 2}

Tables 3 and 4 show the results of hemolysis induced by dialuric acid, TBARS in $\mathrm{RBC}$ and liver, and $\alpha$-Toc concentrations in the tissues after feeding a vitamin E- 
Table 1. Effect of protein level in diets on $\alpha$-tocopherol and free cholesterol levels in $\mathrm{RBC}$, and $\alpha$-tocopherol and total cholesterol in serum of rats (Exp. 1).

\begin{tabular}{cccccc}
\hline \multirow{2}{*}{ Group } & \multicolumn{2}{c}{ RBC } & & \multicolumn{2}{c}{ Serum } \\
\cline { 2 - 3 } \cline { 5 - 6 } & $\begin{array}{c}\alpha \text {-Toc } \\
(\mu \mathrm{g} / \mathrm{ml} \text { packed cell })\end{array}$ & $\begin{array}{c}\text { Free cholesterol } \\
(\mathrm{mg} / \mathrm{dl} \text { packed cell })\end{array}$ & & $\begin{array}{c}\alpha \text {-Toc } \\
(\mu \mathrm{g} / \mathrm{ml})\end{array}$ & $\begin{array}{c}\text { Total cholesterol } \\
(\mathrm{mg} / \mathrm{dl})\end{array}$ \\
\hline $20 \%$ Casein & $6.1 \pm 1.0^{*}$ & $105.2 \pm 4.2^{*}$ & & $6.8 \pm 0.8^{*}$ & $67.5 \pm 7.4$ \\
$10 \%$ Casein & $5.0 \pm 0.5^{\mathrm{a}}$ & $129.0 \pm 6.3^{\mathrm{a}}$ & & $6.7 \pm 0.7$ & $68.0 \pm 7.7$ \\
$20 \%$ SPI & $4.3 \pm 0.7^{\mathrm{a}}$ & $107.6 \pm 10.1$ & & $6.1 \pm 1.6$ & $65.3 \pm 7.8$ \\
\hline
\end{tabular}

${ }^{*}$ Mean \pm SD. ${ }^{\text {a }}$ Significantly different from $20 \%$ casein group $(p<0.05)$.

Table 2. The effect of diet protein levels upon $\alpha$-tocopherol concentration in tissues of rats.

\begin{tabular}{lllll}
\hline \multicolumn{1}{c}{ Group } & Liver* & Kidney* & Lung* & Muscle* $^{*}$ \\
\hline $20 \%$ Casein & $40.0 \pm 8.5$ & $25.1 \pm 2.9$ & $45.2 \pm 4.8$ & $16.4 \pm 3.0$ \\
$10 \%$ Casein & $37.5 \pm 6.0$ & $21.4 \pm 6.0^{\mathrm{b}}$ & $35.2 \pm 4.6^{\mathrm{c}}$ & $13.5 \pm 0.8^{\mathrm{b}}$ \\
$20 \%$ SPI & $33.0 \pm 9.0^{\mathrm{a}}$ & $19.8 \pm 2.6^{\mathrm{b}}$ & $30.7 \pm 5.0^{\mathrm{c}}$ & $13.2 \pm 2.2^{\mathrm{b}}$ \\
\hline
\end{tabular}

$* \mu \mathrm{g} / \mathrm{g}$ fresh tissue. Mean $\pm \mathrm{SD}$. Values within column sharing a superscript letter differ significantly from $20 \%$ casein group $\left({ }^{\mathrm{a}} p<0.05,{ }^{\mathrm{b}} p<0.01,{ }^{\mathrm{c}} p<0.001\right)$.

Table 3. Hemolysis of RBC with dialuric acid and TBARS in erythrocyte and liver from vitamin E-deficient rats (Exp. 2).

\begin{tabular}{|c|c|c|c|}
\hline \multirow[b]{2}{*}{ Group } & \multirow[b]{2}{*}{ Hemolysis } & \multicolumn{2}{|c|}{ TBARS } \\
\hline & & $\begin{array}{c}\mathrm{RBC} \\
\text { (MDA nmol/ml packed cell) }\end{array}$ & $\begin{array}{c}\text { Liver } \\
(\text { MDA nmol/g) }\end{array}$ \\
\hline $40 \%$ Casein & $88.3 \pm 7.5^{*}$ & $2.1 \pm 0.3$ & $105.0 \pm 27$ \\
\hline $20 \%$ Casein & $84.2 \pm 6.6$ & $2.6 \pm 0.4$ & $98.9 \pm 27$ \\
\hline $10 \%$ Casein & $81.8 \pm 18.8$ & $2.7 \pm 0.4$ & $108.0 \pm 27$ \\
\hline
\end{tabular}

deficient diet for 6 weeks, respectively. Table 5 shows $\alpha$-Toc and free cholesterol concentrations in RBC, and $\alpha$-Toc and total cholesterol in serum in rats fed an $\alpha$ Toc-supplemented diet for 3 days after 6 -week administration of $\alpha$-Toc-deficient diets. Table 6 shows $\alpha$-Toc concentrations in the tissues, liver, kidney, lung, heart and muscle of the same rats. In this experiment protein levels in diets were kept at 10,20 and $40 \%$ with casein alone. 
Table 4. $\alpha$-Tocopherol levels in liver, kidney, lung, heart and muscle of vitamin Edeficient rats (Exp. 2).

\begin{tabular}{cccccc}
\hline Group & Liver* & Kidney* & Lung* & Heart* & Muscle* \\
\hline $40 \%$ Casein & $2.70 \pm 0.67$ & $3.98 \pm 0.17$ & $3.99 \pm 0.98$ & $5.39 \pm 0.35$ & $2.90 \pm 0.55$ \\
$20 \%$ Casein & $2.33 \pm 0.13$ & $2.91 \pm 0.02$ & $3.46 \pm 0.31^{\mathrm{b}}$ & $4.51 \pm 0.37^{\mathrm{c}}$ & $2.50 \pm 0.20$ \\
$10 \%$ Casein & $2.08 \pm 0.62$ & $2.44 \pm 0.43^{\mathrm{a}}$ & $2.69 \pm 0.63^{\mathrm{b}}$ & $4.13 \pm 0.53^{\mathrm{c}}$ & $2.39 \pm 0.48$ \\
\hline
\end{tabular}

$* \mu \mathrm{g} / \mathrm{g}$ fresh tissue. Mean $\pm \mathrm{SD}$. Values within column sharing a superscript letter differ significantly from $40 \%$ casein group $\left({ }^{\mathrm{a}} p<0.05,{ }^{\mathrm{b}} p<0.01,{ }^{\mathrm{c}} p<0.001\right)$.

Table 5. $\alpha$-Tocopherol levels in liver, kidney, lung, heart and muscle of vitamin Erefed rats (Exp. 2).

\begin{tabular}{cccccc}
\hline Group & Liver & Kidney & Lung & Heart & Muscle \\
\hline & \multicolumn{5}{c}{$(\mu \mathrm{g} / \mathrm{g}$ fresh weight $)$} \\
$40 \%$ Casein & $15.9 \pm 3.6^{*}$ & $7.49 \pm 0.66$ & $14.8 \pm 1.8$ & $11.3 \pm 1.8$ & $3.74 \pm 0.20$ \\
$20 \%$ Casein & $17.7 \pm 3.2$ & $6.18 \pm 0.40^{\mathrm{a}}$ & $12.7 \pm 1.3^{\mathrm{c}}$ & $10.7 \pm 1.3$ & $3.27 \pm 0.22^{\mathrm{e}}$ \\
$10 \%$ Casein & $14.8 \pm 2.9$ & $4.20 \pm 0.50^{\mathrm{b}}$ & $12.3 \pm 1.3^{\mathrm{c}}$ & $8.75 \pm 0.8^{\mathrm{d}}$ & $2.91 \pm 0.51^{\mathrm{e}}$ \\
\hline
\end{tabular}

$*$ Mean \pm SD. ${ }^{a, c}$ and ${ }^{e}$ superscript letters mean a significant difference from $40 \%$ casein group $\left({ }^{\mathrm{a}} p<0.001,{ }^{\mathrm{c}} p<0.05,{ }^{\mathrm{e}} p<0.01\right) .{ }^{\mathrm{b}}$ and ${ }^{\mathrm{d}}$ superscript letters mean a significant difference from $20 \%$ and $40 \%$ casein groups $\left({ }^{\mathrm{b}} p<0.001,{ }^{\mathrm{d}} p<0.05\right)$.

Table 6. $\alpha$-Tocopherol and free cholesterol levels in erythrocyte and $\alpha$-tocopherol and total lipids in serum of vitamin E-refed rats (Exp. 2).

\begin{tabular}{cccccc}
\hline \multirow{2}{*}{ Group } & \multicolumn{2}{c}{ Erythrocyte } & & \multicolumn{2}{c}{ Serum } \\
\cline { 2 - 3 } \cline { 5 - 6 } & $\begin{array}{c}\alpha \text {-Toc } \\
(\mu \mathrm{g} / \mathrm{ml} \text { packed cell })\end{array}$ & $\begin{array}{c}\text { Free cholesterol } \\
(\mathrm{mg} / \mathrm{dl} \text { packed cell })\end{array}$ & & $\begin{array}{c}\alpha-\mathrm{Toc} \\
(\mu \mathrm{g} / \mathrm{ml})\end{array}$ & $\begin{array}{c}\text { Total lipids } \\
(\mathrm{mg} / \mathrm{dl})\end{array}$ \\
\hline $40 \%$ Casein & $2.99 \pm 0.46^{*}$ & $122 \pm 10$ & & $3.65 \pm 0.25$ & $135 \pm 1.5$ \\
$20 \%$ Casein & $3.15 \pm 0.24$ & $117 \pm 7.2$ & & $4.17 \pm 0.97$ & $131 \pm 22.0$ \\
$10 \%$ Casein & $2.83 \pm 0.40$ & $125 \pm 12$ & & $4.50 \pm 0.59^{\mathrm{a}}$ & $158 \pm 22.0^{\mathrm{b}}$ \\
\hline
\end{tabular}

${ }^{*}$ Mean \pm SD. ${ }^{a}$ Significantly different from. $40 \%$ casein group $(p<0.05)$. ${ }^{\mathrm{b}}$ Significantly different from $40 \%$ and $20 \%$ casein groups $(p<0.05)$.

Hemolysis induced by dialuric acid and TBARS of RBC and liver did not differ among the groups (Table 3 ). $\alpha$-Toc in RBC in each group was not detectable by HPLC. The $\alpha$-Toc concentration in each tissue of vitamin E-deficient rats (Table 4) was low, compared with the vitamin E-supplemented groups as shown in Table 5. It is noteworthy that a higher protein diet with $40 \%$ casein prevents the decrease of 
$\alpha$-Toc levels in tissues, especially in lung and heart, as shown in Table 4 . No difference in free cholesterol in RBC was found among the groups (Table 6).

Vitamin $\mathrm{E}$ supplementation for 3 days after administration of a vitamin Edeficient diet for 6 weeks increased the levels of $\alpha$-Toc in every tissue and in serum and RBC (Tables 5 and 6). The $40 \%$ casein group showed the highest $\alpha$-Toc concentrations in kidney, lung and muscle. In heart, the $40 \%$ and $20 \%$ casein groups had significantly higher $\alpha$-Toc levels than the $10 \%$ casein group, but $\alpha$-Toc in RBC and liver was not significantly different among the groups (Tables 5 and 6). Serum total lipids was significantly higher in the $10 \%$ casein group than in the other two groups.

\section{DISCUSSION}

1. Experiment 1. In a previous paper, it was shown that a low protein diet or a diet with poorer proteins (SPI) caused tocopherol concentrations in RBC to decrease as compared with the control diet group. The present data are consistent with the previous results, because in the rats on a low $(10 \%)$ casein diets and a diet consisting of poor quality proteins (SPI), tocopherol concentrations in RBCs were low, as compared with the control group ( $20 \%$ casein). Although it is well known that tocopherol concentrations in serum(18) and RBC are affected by lipid concentrations in serum, so that a higher tocopherol concentration in hyperlipemic serum is accompanied by a lower RBC tocopherol concentration, our previous and present data show that there are no changes in serum lipids, $\mathrm{RBC}$ tocopherol concentrations decreased by poor quality and a small quantity of dietary proteins. In addition, it was confirmed in this study that in spite of the intake of the same amount of viatmin $\mathrm{E}$, a decrease in tocopherol concentrations in tissues (except for liver) was also documented when dietary proteins were low, and there was a decrease in the $\mathrm{RBC}$ tocopherol concentration as well. From these findings, we assume that intake of low-protein diets may decrease the efficacy of tocopherol transport from blood to tissue cells, and furthermore, it may be difficult to maintain adequate tocopherol into the cells, secondary to a decrease in circulating proteins containing tocopherol (lipoproteins) in blood and a decrease in cytosol binding proteins to tocopherol in the cells, respectively. However, in the liver, no significant changes were observed in the low-protein diet group. Since liver may be a depositary organ for tocopherol, thus differing from other tissues, a decrease in tocopherol in liver occur last among tissues as tocopherol deficiency occurs. On the other hand, changes in tocopherol concentrations in RBCs were found to reflect those in tissues examined, except for liver. Mino et al.(8) proposed that RBC tocopherol is an expression of the nutritional vitamin E status, apart from the Horwitt's index of plasma tocopherol expressed in terms of total lipids (the tocopherol/lipids ratio) which was previously thought to be a very reliable index of vitamin E status (19). Our results agree with the view that $\mathrm{RBC}$ tocopherol is an extremely good index for the assessment of bioavailable vitamin $\mathrm{E}$. 
From the results on the effect of SPI, the quality of protein is also known to influence the vitamin E nutritional status. Two hypotheses may be suggested to account for this: 1) the lower protein score of SPI than that of casein, and 2) secondary to cholesterol changes as indicated in previous reports, in which SPI was shown to reduce serum cholesterol(20-23). The mechanism however remains to be solved. In our present study, the low-protein diet $(10 \%$ casein) induced an elevation of cholesterol in $\mathrm{RBC}$, indicating that membrane cholesterol may be affected by protein content in diet. Nakagawa (24) reported that a negative correlation was shown in RBC in normal children between membrane cholesterol and tocopherol. Our result thus agreed with Nakagawa's observation. However, when comparing the $20 \%$ casein group and the $20 \%$ SPI group, there was no difference in RBC cholesterol concentrations, while tocopherol concentrations were lower in the SPI group than in the casein group. This difference is yet unexplainable and remains to be studied further.

2. Experiment 2. Experiment 2 was undertaken to investigate the effect of dietary protein intake on vitamin E-deficient RBC and tissues, and additionally, the effect on the tocopherol levels after refeeding with a vitamin E-supplemented diet in vitamin E-deficient rats. After consuming deficient diets for 6 weeks, almost complete hemolysis induced by dialuric acid was documented in all the groups receiving the three amounts of dietary protein, indicating development of vitamin $E$ deficiency. Differences in the amounts of protein intake did not affect lipid peroxidation in the liver and $\mathrm{RBC}$, as shown in the TBARS levels. This may possibly be due to similar tocopherol concentrations in the RBC and liver among the three groups (Table 4). In addition to liver and muscle, a significant reduction of tocopherol concentrations occurred in the lowest protein group as compared with the highest one. In the $20 \%$ group tocopherol concentrations in tissues showed moderate elevation from the lowest group, but the difference was not significant. For long-term deficiency of vitamin $\mathrm{E}$, a higher intake of protein than the regular level $(20 \%)$ would be needed to maintain a higher concentration of tocopherol in tissues. This finding suggests that either consumption of tocopherol in tissues becomes greater or the retention of tocopherol in tissues becomes smaller in lowprotein nutrition. This tendency was more clear in the increment of tocopherol concentration in rats which recovered from vitamin $\mathrm{E}$ deficiency after administration of a vitamin E-supplemented diet for 3 days. These results in Exp. 2 were slightly different from those in Exp. 1, because in the former a significant difference in tocopherol concentrations in tissues in vitamin E-deficient rats were observed only in kidney, lung and heart between the $40 \%$ casein and the other groups, while in the latter it was additionally found between the $20 \%$ and $10 \%$ casein groups. We think that this difference comes from a decrease in the retention of tocopherol in the body after a 6-week deficiency. Since after long-term deficiency the concentrations of tocopherol in tissues became quite small, we could not observe a statistically significant difference in tissues betwen the $20 \%$ and $10 \%$ casein groups, but a tendency of decrease was shown. Although after refeeding vitamin E for 3 days 
tocopherol was transported into every tissue cell, a difference might occur in the rate of incorporation of tocopherol among tissue cells. Thus, recovery from vitamin $\mathrm{E}$ deficiency may differ among tissues. This also indicates that protein nutrition may affect the tocopherol nutritional status through changes in the transporting proteins in serum and/or binding proteins in cells. However, RBC and liver tocopherol concentrations were not different among the three groups, in which serum cholesterol levels were twice as high as those in the rats sufficient in vitamin E (Exp. 1). A high concentration of cholesterol may suppress the transportation of tocopherol to RBC. There are many problems remaining to be solved. Further study should lead to an explanation of the respective problems.

This work was supported in part by a Grant-in-Aid (No. 60303028) for Scientific Research from the Ministry of Education, Science and Culture of Japan.

\section{REFERENCES}

1) Mouri, K., Esaka, T., and Igarashi, O. (1984): Effect of dietary protein, and dietary and internal lipids on vitamin E transfer between blood and tissues in rats. J. Jpn. Soc. Nutr. Food Sci., 37, 441-446.

2) Bjornson, L. K., Kaydon, H. J., Miller, E., and Moshell, A. N. (1976): The transport of $\alpha$-tocopherol and $\beta$-carotene in human blood. J. Lipid Res., 17, 343-352.

3) Kitabchi, A. E., and Wimalasena, J. (1982): Demonstration of specific binding sites for ${ }^{3}$ H-RRR- $\alpha$-tocopherol on human erythrocytes. Ann. N.Y. Acad. Sci., 393, 300-314.

4) Rajaram, O. V., Fatterpacker, P., and Sreenivasan, A. (1973): Occurrence of $\alpha$ tocopherol binding protein in rat liver cell sap. Biochem. Biophys. Res. Commun., 52, 459-465.

5) Catignani, G. L., and Bieri, J. G. (1977): Rat liver $\alpha$-tocopherol binding protein. Biochim. Biophys. Acta, 497, 349-357.

6) Murphy, D. J., and Mavis, R. D. (1981): Membrane transfer of $\alpha$-tocopherol. J. Biol. Chem., 256, 10464-10468.

7) Mowri, H., Nakagawa, Y., Inoue, K., and Nojima, S. (1981): Enhancement of the transfer of $\alpha$-tocopherol between liposomes and mitochondria by rat liver protein(s). Eur. J. Biochem., 117, 537-542.

8) Mino, M., Nakagawa, S., Kitagawa, M., Kasugai, O., and Miki, M., (1983): Bioavailable tocopherol. Bitamin (Vitamins) (J. Vitamin Soc. Jpn.), 57, 165-175.

9) Harper, A. E. (1959): Amino acid balance and imbalance. I. Dietary level of protein and amino acid imbalance. J. Nutr., 68, 405-418.

10) Smith, L. I., Ungnade, H. E., Hoehn, H. H., and Wowzonek, S. (1939): The chemistry of vitamin E (part V). J. Org. Chem., 4, 309-311.

11) Mouri, K., Dohmoto, T., Ikesu, H., and Igarashi, O. (1983): A simple elimination method of vitamin $\mathrm{E}$ from vegetable and fish oils for the preparation of vitamin $\mathrm{E}$ deficient diet. J. Jpn. Soc. Nutr. Food Sci., 36, 122-124.

12) Abe, K., and Katsui, G. (1975): Determination of tocopherols in serum by high speed liquid chromatography. Bitamin (Vitamins) (J. Vitamin Soc. Jpn.), 49, 259-263.

13) Ishibashi, K., Abe, K., Ohmae, M., Kawabe, Y., and Katsui, G. (1977): Determination of tocopherols in red blood cells by high speed liquid chromatography. Bitamin (Vitamins) (J. Vitamin Soc. Jpn.), 51, 415-422. 
14) Abe, K., Ohmae, M., and Katsui, G., (1976): Rapid and micro-method for the determination of tocopherols in liver. Bitamin (Vitamins) (J. Vitamin Soc. Jpn.), 50, 453-457.

15) Rose, H. G., and Oklander, M. (1965): Improved procedure for the extraction of lipid from erythrocyte. J. Lipid Res., 6, 428-431.; Shibata, S., Takemoto, Y., and Shibata, K. (1980): Application of Iatroscan for the analysis of lipids from erythrocyte membrane. Clin. Lab. (in Japanese), 21, 837-844.

16) Brownlee, N. R., Huttner, J. J., Panganamala, R. V., and Cornwell, D. G., (1977): Role of vitamin $\mathrm{E}$ in glutathione-induced oxidant stress; methemyoglobin, lipid peroxidation, and hemolysis. J. Lipid Res., 18, 635-644.

17) Uchiyama, M., and Mihara, M. (1978): Determination of malondialdehyde precursor in tissues by thiobarbituric acid test. Anal. Biochem., 86, 279-286.

18) Bieri, J. G., Everts, R. P., and Sylvia, T. (1977): Factors affecting the exchange of tocopherol between red blood cell and plasma. Am. J. Clin. Nutr., 30, 686-690.

19) Horwitt, M. K., Harvey, C. C., Dahm, C. H., Jr., and Searcy, M. T. (1972): Relationship between tocopherol and serum lipid levels determination of nutritional adequacy. Ann. N.Y. Acad. Sci., 203, 223-236.

20) Huff, M. W., and Carroll, K. K. (1980): Effects of dietary protein on turnover, oxidation, and absorption of cholesterol and on steroid excretion in rabbits. J. Lipid Res., 21, 546-558.

21) Nagata, Y., Ishiwaki, N., and Sugano, M. (1982): Studies on the mechanism of antihypercholesterolemic action of soy protein and soy protein-type amino acid mixture in relation to the casein counterparts in rats. J. Nutr., 112, 1614-1625.

22) Kritchevsky, D. (1979): Vegetable protein and atheroscrelosis. J. Am. Oil Chem. Soc., 56, 135-140.

23) Sugano, M., Ishikawa, N., Nagata, Y., and Imaizumi, K. (1982): Effects of arginine and lysine addition to casein and soya-bean protein on serum lipids, apoproteins, insulin and glucagon in rats. Br. J. Nutr., 48, 211-221.

24) Nakagawa, M. (1985): The correlation of levels between vitamin $E$ and lipids in red blood cell membrane of healthy children. Bitamin (Vitamins) (J. Vitamin Soc. Jpn.), 59, $7-13$. 